\title{
Implemantasi Pembelajaran Kurikulum 2013 Berbasis Multimedia Interaktif pada Pokok Bahasan Listrik Magnet terhadap Aktivitas, Persepsi, dan Hasil Belajar Peserta Didik di SMA Tut Wuri Handayani Makassar
}

Fatima, Irfan Yusuf, Hartono Bancong

Program Studi Pendidikan Fisika, Universitas Muhammadiyah Makassar fatima_1301@yahoo.co.id

\begin{abstract}
Abstrak - Telah dilakukan penelitian untuk mengetahui karakteristik multimedia interaktif berdasarkan Kurikulum 2013, akivitas, persepsi, dan hasil belajar Fisika peserta didik pada pokok bahasan listrik dan magnet. Subjek penelitian adalah peserta didik kelas XII IPA SMA Tut Wuri Handayani Makassar yang berjumlah 18 orang. Penelitian ini menggunakan pre ekperimental design. Hasil penelitian menunjukkan bahwa multimedia interaktif materi listrik magnet diperoleh hasil valid dan reliabel, perangkat pembelajaran Kurikulum 2013 berupa Rencana Pelaksanaan Pembelajaran (RPP) dan Lembar Kerja Peserta Didik (LKPD) yang dibuat diperoleh hasil yang valid dan reliabel. Akivitas peserta didik di atas $80 \%$, hal ini menunjukkan bahwa pembelajaran yang dilakukan mampu mengaktifkan peserta didik. Persepsi peserta didik setelah dilakukan pembelajaran berbasis multimedia interaktif pada pokok bahasan listrik magnet di atas $80 \%$, hal ini menunjukkan bahwa peserta didik mengikuti dengan dengan baik pembelajaran yang dilakukan. Hasil belajar peserta didik setelah dilakukan pembelajaran berbasis multimedia interaktif pada pokok bahasan listrik magnet berada pada katagori baik.
\end{abstract}

Kata Kunci: Aktivitas Peserta Didik, Persepsi Peserta Didik, Kurikulum 2013, Listrik Magnet, Multimedia Interaktif

Abstract - A research has been conducted to know the characteristics of interactive multimedia based on Curriculum 2013, learners' activity, students' perception and the students' achievement in learning electricity and magnetism. The sample of the research was 18 students of class XII IPA of SMA Tut Wuri Handayani Makassar. This research was preexperimental design. The result of the research showed that interactive multimedia material of electricity and magnetism is valid and reliable. Teachers' Lesson Plan (RPP) and Students' Work Sheet (Lembar Kerja Peserta Didik) based on Curriculum 2013 showed us a good result of the students' achievement. Learners' Activity is above $80 \%$ indicating that learning was able to activate the learnes. The students' perception in learning electricity and magnetism trough Interactive Multimedia was above $80 \%$ indicating that the students following the learning process well. The students' achievement in learning electricity and magnetism through Interactive Multimedia was categorized as good.

Key Words: Learners' Activity, Students’ Perception, Curriculum 2013, Magnetic Electricity, Interactive Multimedia

\section{PENDAHULUAN}

Perkembangan teknologi dan informasi (TIK) di abad 21 sekarang ini, menjadikan komputer sebagai salah satu kebutuhan primer manusia dalam kehidupan sehari-hari. Salah satu bagian yang berkembang pesat adalah teknologi multimedia. Multimedia merupakan salah satu konsep dari teknologi yang dikemas dalam berbagai bentuk teks, suara, gambar, dan animasi yang dapat dimodifikasi sedemikian rupa sehingga tampak lebih menarik, interaktif, dan lebih bersifat edukatif.

Hasil belajar peserta didik dapat dioptimalkan dengan upaya meningkatkan kualitas pembelajaran di sekolah. Berdasarkan Kurikulum Tingkat Satuan Pendidikan (KTSP) yang telah direvisi melalui Kurikulum 2013 yang mengacu pada standar nasional pendidikan bertujuan untuk mempersiapkan manusia Indonesia agar memiliki kemampuan hidup sebagai pribadi dan warga negara yang beriman, produktif, kreatif, inovatif, dan efektif serta mampu berkontribusi pada kehidupan bermasyarakat, berbangsa, bernegara, dan peradaban dunia. Perubahan tersebut harus diikuti oleh guru yang bertanggung jawab atas penyelenggaraan pembelajaran di sekolah. Hal ini karena peranan guru sebagai fasilitator yang membantu peserta didik dalam memecahkan masalah dalam proses pembelajaran.

Sejalan dengan perkembangan fisika di abad 21 sekarang ini, menjadikan Fisika sebagai salah satu mata pelajaran yang tidak hanya terpaku pada mata pelajaran Ilmu Pengetahuan Alam (IPA) saja, akan tetapi, mencakup ranah arsitektur, teknologi, elektronik, dan sebagainya. Namun, salah satu masalah dalam pembelajaran fisika adalah rendahnya kualitas pembelajaran yang berdampak pada hasil belajar peserta didik yang tidak mencapai standar Kriteria Ketuntasan Minimal (KKM). Kualitas proses dan hasil belajar fisika ditentukan oleh banyak faktor, salah satunya adalah sarana laboratorium. Kegiatan laboratorium merupakan hal penting dalam pembelajaran fisika, ini disebabkan agar peserta didik memiliki pengalaman yang lebih bermakna dalam proses pembelajaran yang dialaminya.

Keberhasilan kegiatan laboratorium ditentukan oleh sumber daya yang mencakup bahan dan peralatan, ruang, 
alat, tenaga laboran, dan teknisi dalam pelaksanaan pembelajaran. Namun, percobaan yang berupa konsepkonsep abstrak tidak mendukung untuk diselenggarakannya kegiatan laboratorium, sehingga diperlukan terobosan baru dalam proses pembelajaran.

Berdasarkan temuan peneliti di SMA Tut Wuri Handayani Makassar, hasil belajar peserta didik pada mata pelajaran Fisika secara rata-rata belum mencapai standar KKM. Peserta didik mengalami kesulitan dalam memahami konsep fisika terutama yang berkaitan dengan praktikum. Berdasarkan permasalahan tersebut, solusinya adalah melakukan pengimplementasian Kurikulum 2013 berbasis multimedia interaktif (MMI), dengan mengintegrasikan semua mata pelajaran dengan TIK. Artinya, peserta didik akan benar-benar merasa belajar langsung melalui eksperimen, demonstrasi, dan kunjungan lapangan. Peserta didik dapat belajar sendiri dengan menggunakan media pembelajaran atau bahan ajar berbasis TIK. Dengan mengklik satu tombol peserta didik seolah-olah berada pada dunia nyata. Suasana belajar seperti itu yang dimaksudkan jika TIK terintegrasi pada semua mata pelajaran.

MMI merupakan suatu multimedia yang dilengkapi dengan alat pengontrol yang dapat dioperasikan oleh pengguna, sehingga pengguna dapat memilih apa yang dikehendaki untuk proses selanjutnya. MMI menggunakan komputer untuk menyusun penggunaan informasi yang disimpan dalam berbagai bentuk, termasuk teks, grafis, suara, video, dan animasi. Melalui media komputer, materi pelajaran dapat lebih cepat diterima peserta didik secara utuh serta menarik minat mereka untuk belajar lebih lanjut[1]. Guru memainkan peranan penting sebagai fasilitator dalam penggunaan media komputer dalam pembelajaran, untuk meningkatkan pemahaman peserta didik terhadap materi pelajaran[2]. dengan mengkombinasikan berbagai media dalam pembelajaran merangsang kecerdasan, imajinasi dan bakat peserta didik untuk bersungguh-sungguh memperluas pengetahuannya terus-menerus. Sehingga MMI dapat didefenisikan sebagai sebuah media yang menggabungkan beberapa media yang mendukung proses pembelajaran berbasis TIK.

Salah satu konsep Fisika yang bersifat abstrak dan tidak dengan mudah dilihat secara langsung yaitu konsep induksi elektromagnetik. Induksi elektromagnetik mempelajari bagaimana arus listrik dapat menghasilkan gaya magnet baik di sekitar kawat lurus berarus listrik maupun di sekitar kawat melingkar berarus listrik. Untuk menggambarkan induksi magnet perlu digunakan media yang dapat menjelaskan proses terjadinya induksi magnet tersebut. Sehingga, peneliti merancang MMI untuk mensimulasikan percobaan secara virtual. Hal ini dikarenakan laboratorium virtual dapat mendukung kegiatan praktikum yang bersifat interaktif, dinamis, animatif, dan berlingkungan virtual sehingga tidak membosankan dan dapat mendukung keinginan pengguna untuk mempelajari dan memahami materi pelajaran produktif [3].

Penelitian ini dilakukan untuk menjawab masalah sebagai berikut : 1) Bagaimanakah karakteristik multimedia interaktif (MMI) berdasarkan Kurikulum 2013?; 2) Bagaimanakah aktivitas peserta didik pada saat dilakukan pengimplementasian Kurikulum 2013 berbasis MMI pada pokok bahasan listrik magnet?; 3) Bagaimanakah persepsi dan hasil belajar peserta didik setelah dilakukan pengimplementasian Kurikulum 2013 berbasis MMI pada pokok bahasan listrik magnet?.

\section{METODE PENELITIAN}

Penelitian ini merupakan penelitian kuantitatif yang mendeskripsikan implemantasi pembelajaran Kurikulum 2013 berbasis MMI pada pokok bahasan listrik magnet terhadap hasil belajar peserta didik kelas XII IPA di SMA Tut Wuri Handayani Makassar. Desain penelitian yang digunakan adalah one-shot case study (Sugiyono, 2013). Pengambilan subjek penelitian menggunakan purposive random sampling. Instrumen yang digunakan dalam penelitian ini adalah instrumen aktivitas peserta didik, instrumen hasil belajar peserta didik, dan angket persepsi peserta didik terhadap pembelajaran fisika berbasis MMI.

Data yang diperoleh dari angket persepsi peserta didik terhadap pembelajaran fisika berbasis MMI dianalisis dengan menggunakan coding, kemudian dideskripsikan secara kualitatif dan penggambaran data secara kontinum untuk mengetahui kategori penilaian. Selanjutnya, data dari instrumen aktivitas peserta didik dianalisis dan ditafsirkan dalam pengertian kualitatif. Penilaian validitas dan realibilitas dilakukan oleh ahli media dan materi. Kemudian data yang diperoleh dari instrumen hasil belajar peserta didik dibandingkan dengan nilai Kriteria Ketuntasan Minimal (KKM), dikatakan tuntas jika diperoleh persentase ketuntasan klasikal di atas $80 \%$ atau berada pada kategori baik.

\section{HASIL DAN PEMBAHASAN}

Pada hasil analisis pendefinisian menunjukkan bahwa peserta didik kelas XII IPA SMA Tut Wuri Handayani Makassar telah mempelajari materi prasyarat seperti listrik dan gelombang elektromagnetik. Dari segi bahasa yang digunakan peserta didik umumnya menggunakan bahasa Indonesia.

Analisis tugas yang dirancang dituangkan dalam Lembar Kerja Peserta Didik (LKPD) yang harus diselesaikan oleh peserta didik selama proses pembelajaran di kelas. Begitu pula dengan evaluasi dalam Buku Bacaan Peserta Didik (BBPD) diselesaikan di luar jam pelajaran. Dari tugas-tugas tersebut, peserta didik aktif melakukan percobaan virtual dan mengevaluasi pemahaman mereka tentang materi yang dipelajari. Selanjutnya, hasil analisis konsep meliputi analisis materi yang diajarkan yaitu proses terjadinya GGL induksi, faktor-faktor yang mempengaruhi GGL induksi, dan penerapan GGL induksi dalam kehidupan sehari-hari, disesuaikan dengan Kompetensi Inti (KI) dan Kompetensi Dasar (KD).

Pemilihan dan penggunaan media berupa penggambaran keadaan yang bersifat abstrak, sesuai dengan tujuan, konsep, kondisi lingkungan, dan fasilitas serta waktu yang disediakan untuk kebutuhan pembelajaran. Berbagai software yang digunakan dalam 
pembuatan MMI ini yaitu AutoPlay Media Studio 7.5 untuk menampilkan autorun.exe sebagai tampilan awal saat CD dimasukkan ke komputer, Foxit Reader untuk menampilkan petunjuk penggunaan MMI, KI dan KD, Rencana Program Pembelajaran (RPP), LKPD, dan BBPD., Java dan Adobe Flash CS6 untuk menampilkan unit kegiatan yang diunduh dari aplikasi Physics Education Technology (PhET) Simulations, serta Audacity dan Bagus ispiring. Suite.6.0.0 digunakan untuk membuat suara tutorial pada awal MMI dijalankan. Pengembangan MMI ini dapat menyelesiakan permasalahan belajar yang dialami peserta didik dalam pengimplementasian Kurikulum 2013 pada proses pembelajaran di abad 21 ini serta permasalahan biaya yang diperlukan untuk melakukan kegiatan paraktikum di sekolah.

Program MMI yang dibuat, berisi materi yang dilengkapi dengan gambar, animasi, dan simulasi interaktif. Kelengkapan tersebut membantu peserta didik memahami konsep induksi elektromagnetik dengan baik. Gambar 1 memperlihatkan tampilan program MMI proses terjadinya induksi elektromagnetik yang digunakan.

Pada percobaan virtual proses terjadinya induksi elektromagnetik, disediakan bohlam, magnet batang, galvanometer, dan dua buah kumparan yang jumlah dari masing-masing lilitannya berbeda. Untuk melakukan percobaan virtual pada materi tersebut, peserta didik menggerakkan magnet batang ke dalam dan keluar kumparan yang selanjutnya besar arus induksi yang ditimbulkan dapat dilihat dari nyala bohlam dan besarnya penyimpangan yang terjadi pada jarum galvanometer. Selanjutnya, Gambar 2 memperlihatkan tampilan program MMI pada percobaan virtual materi faktorfaktor yang mempengaruhi besar GGL induksi yang digunakan.

Pada percobaan virtual materi faktor-faktor yang mempengaruhi besar GGL induksi. Pada percobaan ini diawali dengan menggeser scroll boxes untuk mengalirkan air yang berdampak pada terjadinya pergerakan pada magnet. Selanjutnya, mengatur kekuatan magnet dan kemudian besar arus induksi akan terlihat pada penyimpangan jarum galvanometer. Percobaan ini dilakukan sebanyak dua kali dengan cara mengatur ulang kekuatan magnet dengan catatan kekuatan magnet pada saat parcobaan pertama tidak sama dengan kekuatan magnet yang ke dua, hal ini bertujuan agar peserta didik dapat membandingkan besar arus induksi yang timbul pada saat kekuatan magnet yang digunakan besar dengan kekuatan magnet yang digunakan kecil. Selanjutnya, dengan kekuatan magnet tetap, scroll boxes yang terdapat pada aliran air digeser lebih jauh sehingga pergerakan magnet menjadi lebih cepat dari keadaan sebelumnya. Kemudian, perbedaan besar arus induksi yang terjadi dapat dilihat kembali pada penyimpangan jarum galvanometer. Dengan demikian, akan terlihat jelas perbedaan antara besar arus induksi yang timbul pada saat megnet yang perputarannya cepat dengan lambat di depan kumparan. Selanjutnya, dengan mengatur area lilitan semula ke area lilitan yang lebih luas, maka perbedaan besar arus induksi yang terjadi akan kembali terlihat pada besar penyimpangan jarum galvanometer.

Pada tahap pengembangan perangkat pembelajaran, LKPD dilengkapi dengan materi pengantar untuk memberikan pengetahuan dasar kepada peserta didik sebelum melakukan percobaan virtual. BBPD menguraikan materi induksi elektromagnetik secara runtun yang dilengkapi dengan gambaran percobaan virtual, dan evaluasi. Instrumen aktivitas menguraikan aktivitas peserta didik yang mungkin selama proses pembelajaran. Instrumen hasil belajar peserta didik menguraikan soal-soal yang sesuai dengan tujuan pembelajaran.

Validasi ahli dan materi dilakukan oleh dua orang ahli yang merupakan dosen fisika di Universitas Negeri Makassar. Berdasarkan penilaian perangkat pembelajaran oleh validator, diperoleh hasil valid dan reliabel untuk setiap pernyataan yang diberikan. Hal ini berarti bahwa MMI, RPP, LKPD, BBPD, instrumen aktivitas peserta didik, angket persepsi peserta didik dan instrumen hasil belajar peserta didik dapat digunakan. Aktivitas peserta didik pada tahap uji coba dapat dilihat pada Gambar 3.

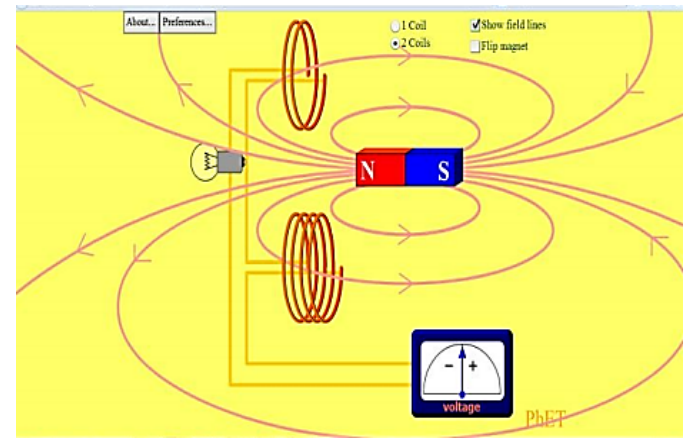

Gambar 1. Tampilan percobaan virtual proses terjadinya induksi elektromagnetik.

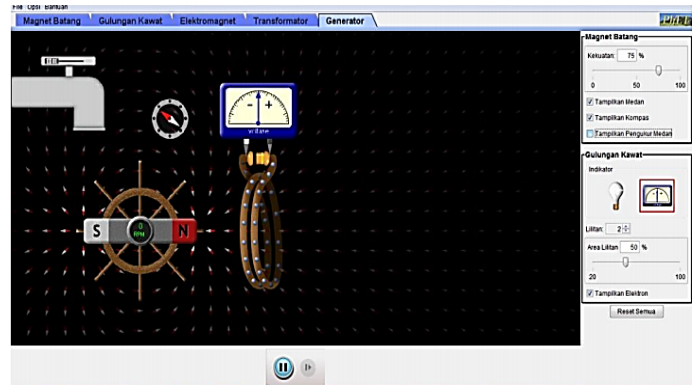

Gambar 2. Tampilan percobaan virtual materi faktor-faktor yang mempengaruhi besar GGL induksi. 


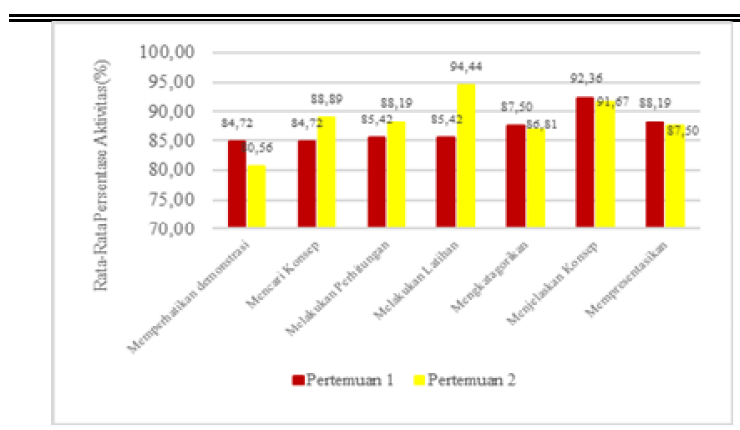

Gambar 3. Aktivitas peserta didik.

Berdasarkan penilaian pengamat dari setiap pertemuan diperoleh bahwa aktivitas peserta didik di atas $80 \%$ yang berarti bahwa pengimplementasian Kurikulum 2013 berbasis MMI memberikan kesempatan kepada peserta didik untuk aktif dalam proses pembelajaran. Hal ini sejalan dengan pendapat Ali (2009) yang menyatakan bahwa diketahui bahwa penerapan pembelajaran interaktif sangat baik untuk mendukung pembelajaran.

Adapun hasil analisis persepsi peserta didik terhadap implementasian Kurikulum 2013 berbasis MMI dapat dilihat pada Tabel 1 .

Tabel 1. Hasil analisis persepsi peserta didik.

\begin{tabular}{clc}
\hline No & \multicolumn{1}{c}{ Indikator } & Rerata Presentase (\%) \\
\hline 1 & Fasilitas MMI & 82,78 \\
2 & Daya tarik belajar dengan & 80,83 \\
& menggunakan MMI & 79,70 \\
3 & Aktivitas belajar dengan & 81,10 \\
\hline
\end{tabular}

Berdasarkan Tabel 1, diperoleh rata-rata persepsi peseta didik terhadap implementasi kurikulum 2013 berbasis MMI di atas $80 \%$ yang menunjukkan bahwa peserta didik sangat setuju terhadap pembelajaran yang dilakukan.

Persepsi peserta didik setelah belajar dengan menggunakan MMI menunjukkan hasil yang sangat setuju, tidak ada peserta didik yang memberikan penilaian tidak setuju dari setiap kriteria yang diajukan. Peserta didik tertarik dengan tampilan simulasi media pembelajaran, mudah dalam menjalankan simulasi interaktif, serta senang belajar dengan menggunakan MMI. Selanjutnya, rata-rata hasil belajar peserta didik setelah diimplementasikannya Kurikulum 2013 berbasis MMI adalah 84,94 dan persentase ketuntasannya adalah $83 \%$. Hal ini menunjukkan bahwa nilai peserta didik tuntas secara klasikal, yaitu berada di atas nilai KKM (75). Hal ini sesuai dengan penelitian Irfan Yusuf (2013) bahwa penerapan pembelajaran berbasi media laboratorium virtual dapat mengaktifkan peserta didik[4]. Laboratorium Virtual juga dapat meningkatkan kemampuan afektif peserta didik yang menggambarkan perasaan, minat, dan sikap terhadap proses pengajaran[5]. Penggunaan media yang tepat dapat meningkatkan persepsi peserta didik sehingga mereka termotivasi dalam belajar. Semakin baik persepsi mereka terhadap pembelajaran, maka semakin baik pula kinerja mereka[6].
Meskipun hasil penelitian ini menunjukkan persepsi, aktivitas, dan hasil belajar peserta didik dalam kategori sangat setuju dan baik. Tidak ada jaminan bahwa percobaan virtual lebih efektif dibanding dengan percobaan di laboratorium nyata. Sebaiknya, percobaan virtual dilakukan dengan alasan keterbatasan alat, pertimbangan waktu, dan materi pembelajaran yang abstrak.

\section{KESIMPULAN}

Karakteristik MMI berdasarkan Kurikulum 2013 antara lain berupa laboratorium virtual yang memvisualisasikan materi fisika abstrak seperti listrik magnet yang disajikan secara interaktif dan bertujuan untuk membantu peserta didik dalam memahami konsep, yang meliputi RPP, LKPD, dan BBPD dirancang dengan maksud memadukan sesi percobaan menggunakan MMI. Materi yang terkait dalam percobaan virtual disertakan dalam perangkat pembelajaran yang dapat dipelajari secara mandiri oleh peserta didik.

Aktivitas peserta didik di atas $80 \%$, menunjukkan pembelajaran yang dilakukan mampu mengaktifkan peserta didik. Persentase persepsi peserta didik adalah $81,10 \%$ yang menunjukkan bahwa peserta didik sangat setuju terhadap pembelajaran fisika berbasis MMI. Selanjtnya, rata-rata hasil belajar peserta didik adalah 84,94 dan persentase ketuntasannya adalah $83 \%$. Hal ini menunjukkan bahwa nilai peserta didik tuntas secara klasikal yaitu berada di atas nilai KKM (75), sehingga dapat dikategorikan dalam kategori baik.

\section{PUSTAKA}

[1] K. Gundogdu, F. Silman, and Ozan, C, A Com-parative Study on Perception of Teachers on the Use of Computers in Elementary Schools of Turkey and T.R.N.C. International Online Journal of Educational Sciences, vol. 3, no.1, 2011, pp. 113-137.

[2] T. Kutluca, Investigation of Teachers' Computer Usage Profiles and Attitudes toward Computers. International Online Journal of Educational Sciences vol, 2, no. 1, 2010, pp. 81-97.

[3] H. Jaya, Pengembangan Laboratorium Virtual untuk Kegiatan Praktikum dan Memfasilitasi Pendidikan Karakter di SMK. Jurnal Pendidikan Vokasi vol. 2, no. 1, 2012.

[4] I. Yusuf, Pengembangan Perangkat Pembelajaran Fisika Berbasis Media Laboratorium Virtual pada Materi Dualisme Gelombang Partikel di Sma Tut Wuri Handayani Makassar. Jurnal Pendidikan IPA Indonesia vol. 2, no. 2, 2013, hlm. 189-194.

[5] D. Yulianti, S. Khanafiyah, dan Sugiyanto, Penerapan Virtual Experimentberbasis Inkuiri untuk Mengembangkan Kemandirian Mahasiswa. Jurnal Pendidikan Fisika Indonesia vol. 8, 2012, hlm. 127-134.

[6] K. Daesang, K. Dong-Joong and W. Woo-Hyung, Cognitive Synergy in Multimedia Learning. International Education Studies, vol, 6, no. 4, 2013, pp. 76-84. 